\title{
Potential Recreation Activities at Muallim District Forest Reserve
}

\author{
Jaffry Zakaria1* ${ }^{*}$, Md Amin Md Taff', Mazuki Mohd Yasim¹, Benderi Dasrili', Shariman Shafie², \\ Mahathir Mohamad' ${ }^{3}$, Fatin Hasinah Abdul Razak ${ }^{1}$, Anton Komaini ${ }^{4}$
}

${ }^{1}$ Faculty of Sports Science and Coaching, Sultan Idris Education University, Tanjong Malim, Perak, Malaysia

${ }^{2}$ Faculty of Sports Science and Recreation, MARA University of Technology, Seremban Campus, Seremban, Negeri Sembilan, Malaysia

${ }^{3}$ Department of Wildlife and National Parks Peninsular Malaysia, Cheras, Kuala Lumpur, Malaysia

${ }^{4}$ Faculty of Sport Science, Universitas Ngeri Padang, Kota Padang, Sumatera Barat, Indonesia

Email: *jaffry@fsskj.upsi.edu.my

How to cite this paper: Zakaria, J., Md Amin Md Taff, Yasim, M.M., Dasril, B., Shafie, S., Mohamad, M., Razak, F.H.A. and Komaini, A. (2020) Potential Recreation Activities at Muallim District Forest Reserve. Open Access Library Journal, 7: e6163. https://doi.org/10.4236/oalib.1106163

Received: February 13, 2020

Accepted: September 24, 2020

Published: September 27, 2020

Copyright $\odot 2020$ by author(s) and Open Access Library Inc.

This work is licensed under the Creative

Commons Attribution International

License (CC BY 4.0).

http://creativecommons.org/licenses/by/4.0/

(c) (i) Open Access

\begin{abstract}
The Muallim district area, in Perak State, Malaysia is rich in diversity of flora and fauna. Among the many varieties in the area is the 23,908 hectare Behrang Forest Reserve (HSB) surrounded by stunning flora and fauna. The area is expected to have a variety of potential natural resources for sustainable development. To collect scientific evidence, a study was conducted to provide a potential inventory of recreational activities in the Behrang Forest Reserve area. The study found that Behrang Forest Reserve has a variety of attractive flora and fauna and is ideal for being a location for moderate and high intensity outdoor recreation activities.
\end{abstract}

\section{Subject Areas \\ Sociology, Sports Science}

\section{Keywords}

Forest Reserve, Outdoor Recreation Activities, Flora, Fauna, Sustainable

\section{Introduction}

This study Behrang Forest Reserve has been conducted to identify potential areas for development as an outdoor recreational activity at Behrang Forest Reserve (HSB), Perak State, Malaysia. All area plots were recorded and the evaluation of the proposed activity was carried out. The main objective of this study is to develop the potential for outdoor recreation activities at Behrang Forest Reserve as one of the tourist attractions in Muallim district, Perak. 
Recently, the Ministry of Youth and Sports Malaysia (KBSM) through its registered recreation association has encouraged recreational activities organization to enhance the level of fitness among youth in Malaysia. Meanwhile, the Ministry of Tourism has set a goal of establishing Malaysia as the most popular tourist-based tourism destination in the Asian region. Through these initiatives, both ministries have encouraged the development of as many locations as possible for outdoor recreational activities in Malaysia [1].

However, the above initiatives focus only on areas that have been developed. Among them are encountered when tourists only focus on limited outdoor recreation areas Raub in Pahang, Pulau Kukup in Johor, Setiu in Terengganu and Kerachut Beach in Penang [2]. The literature highlights that the new outdoor recreation area is still under development. As a result, tourists congestion, environmental pollution and deterioration of tourist experience are among the major issues in Malaysia [2].

In the state of Perak which is rich with mountains, beaches and rivers, outdoor recreational tourism development is concentrated only in a few key locations namely the Kinta Valley and Gopeng. Outdoor recreational activities have always been a priority for recreationists [3]. There is no clear data on the development of new locations in this fascinating state of flora and fauna. Although some studies have been conducted in forested areas such as Royal Belum, and in the Kampar District, the study focused only on biodiversity-related studies to look at vegetation inventory only. As a result, the potential for the area to become a tourist attraction is only in the form of leisure activities [4]. Varieties of flora and fauna could be explored in these areas [5].

Muallim district is one of the districts in Perak which is rich in natural attractions. Surrounded by the Titiwangsa Range, Muallim District is dominated by nine interesting mountains, including East and West Liang Mountains, Mount Tumang Batak, Mount Behrang and Mount Sanggul. The Muallim district is also surrounded by a variety of natural rivers and waterfalls that attract tourists from inside and outside the country. Among them are Strata Falls, Gerahang Waterfalls, Warin Falls and Ulu Slim Waterfalls. The majority of these attractions are located in the Behrang Forest Reserve area.

Although rich in many natural attractions, there is still little research being done at Behrang Forest Reserve on the activities that could be done in these areas. In this regard, the study has been conducted to develop a basic inventory of various attractions and outdoor recreation activities that are well implemented in the Behrang Forest Reserve area while making it a location for outdoor recreational tourism attractions.

As Behrang Forest Reserve is a forest reserve located in the Muallim district area and it is believed that various recreational attractions can be seen through this study. However, what are the major attractions of recreational activities in this area? Researchers expect Behrang Forest Reserve to have a wide range of recreational activities and if it is not invented and a list of potential areas will be left to waste. 
The main objective of this research is to conduct a basic study in identifying potential outdoor recreation activities that can be developed at Behrang Forest Reserve. The second phase proposed after this study is to build a complete inventory of existing attractions and proposed infrastructure development to encourage outdoor recreational tourism in the Behrang Forest Reserve area. Some of the interests of this investigation are:

1) Develop a new inventory of outdoor recreation-based tourism locations in Muallim and Perak.

2) Promote this location so that it can be developed as an outdoor recreation based tourism destination.

3) Promote research culture in contemporary recreation and education.

4) The medium of sharing knowledge and practice in the field of recreation and education.

\section{Methodology}

To achieve the stated objectives, this study comprises field study method. According to [6] field survey studies are suitable for location identification and activity inventory as they are easy to see and do. In addition, field studies are also very effective in determining the actual level of risk at the site so that the proposed activities do not pose a danger to visitors to the site.

On-site field studies were carried out and participated by the members involved. The plot was at Behrang Forest Reserve. This plot was chosen because it has existing trails, is safe and attractive to many previous visitors. In addition, this plot was also chosen because it is believed to have interesting flora and fauna. Data and samples were collected throughout the field study. Data and subsequent samples were recorded using the survey method.

\section{Findings}

Based on the data and samples, the researchers found that Behrang Forest Reserve has great potential to serve as a family-friendly outdoor tourism destination to the Malaysian recreational community.

Based on the field studies that have been conducted, the researchers have identified several interesting locations located around the plot of Behrang Forest Reserve study. Among these locations are listed in Table 1.

Based on the findings from the field studies that have been carried out, the researchers have agreed that there are a number of suitable outdoor recreation activities at Behrang Forest Reserve based on the location categories found. These location categories have been classified into 5 categories:
1) The river
2) Waterfall
3) The mountain
4) Flora area
5) Aboriginal village
6) Traditional Malay village 
Based on this category and the risk assessment analysis was carried out using the Risk Assessment Matrix System (RAMS). Researchers have proposed several outdoor recreation-based tourism activities that are appropriate to be conducted in Behrang Forest Reserve area. The suggested activity inventory is listed in Table 2 [7].

Table 1. Location Behrang forest reserve.

\begin{tabular}{ccc}
\hline No & Location & Attraction \\
\hline 1 & Dara River & Natural river \\
2 & Water Plant & Artificial plant water \\
3 & Pelangi Waterfall & Waterfalls \\
4 & Lubuk Hantu & Hollow river \\
5 & Permatang & Campground \\
6 & Taman Lumut (Mass Garden) & Bonsai and moss area \\
7 & Liang Timur Mountian & Peak mountain \\
8 & Liang Barat Mountian & Peak mountain \\
9 & Kampung Orang Asli Behrang & Native area \\
10 & Traditional Malay Village & Traditional village \\
\hline
\end{tabular}

Table 2. Outdoor recreation-based tourism activity inventory at Behrang forest reserve.

\begin{tabular}{|c|c|c|}
\hline Bil & Location Categories & Activity Inventory \\
\hline 1 & River & $\begin{array}{ll}\text { - } & \text { Picnic } \\
\text { - } & \text { Water tubing } \\
\text { - } & \text { Whitewater kayaking } \\
\text { - } & \text { Rock scrambling } \\
\text { - } & \text { River crossing } \\
\text { - } & \text { Fishing } \\
\text { - } & \text { Swiftwater rescue training } \\
\text { - } & \text { Swiftwater diving }\end{array}$ \\
\hline 2 & Waterfalls & $\begin{array}{ll}\text { - } & \text { Picnic } \\
\text { - Waterfall abseiling } \\
\text { - } \\
\text { - } & \text { Sishing } \\
\text { Swiftwater diving }\end{array}$ \\
\hline 3 & Mountain & $\begin{array}{l}\text { - } \text { Climb a mountain } \\
\text { - Review of flora \& fauna } \\
\text { - Trans mountain } \\
\text { - Adventure race } \\
\text { - Sunset/Sunrise watching } \\
\text { - Stargazing }\end{array}$ \\
\hline 4 & Flora Area & - Review of flora \& fauna \\
\hline 5 & Native Village & $\begin{array}{l}\text { - } \text { Suction } \\
\text { - Traditional survival skills } \\
\text { - Traditional cooking skills } \\
\text { - Life crafts } \\
\text { - Traditional medicine } \\
\text { - }\end{array}$ \\
\hline 6 & Traditional Malay Village & $\begin{array}{l}\text { - Container farming activities } \\
\text { (rubber tapping, oil palm, vegetables) } \\
\text { - } \text { Fruit orchard } \\
\text { - Traditional life of Malay } \\
\text { - Fish farming } \\
\text { - }\end{array}$ \\
\hline
\end{tabular}




\section{Aspects of Safety}

Outdoor recreation-based tourism is closely linked to risk. This is because these activities are carried out in an open environment and are exposed to climate change. In this regard, the study also noted some of the risks that should be considered in Behrang Forest Reserve area if it is to be developed as a tourist destination.

1) Safety/emergency assistance location nearby

- Police station

- Hospital/clinic

- Nearby villages

2) Phone coverage

- The researchers found that Behrang Forest Reserve area had satisfactory mobile phone coverage near the entire plot studied.

- This scenario facilitates any communication process in the event of an emergency.

3) Weather

- Behrang Forest Reserve is located in the Muallim district which receives the highest rainfall distribution in Peninsular Malaysia. As such, it is exposed to three major natural scenarios:

a) Flash floods and water heads

b) Lightning bolt

c) Collapsed land/tree crops

- Therefore, the proposed location to be developed should take into account each of these risks.

4) Wildlife

- Researchers have found that Behrang Forest Reserve area is rich in flora and fauna [8].

- During field research, there were traces and sites of animals such as deer, tapir and tiger roots.

- There were also traces and presence of toxic animals such as snakes, monkeys and fire ants.

- Therefore, any development of campsites in Behrang Forest Reserve area should take into account the risk of these animals.

Based on the RAMS analysis, the risk categories Behrang Forest Reserve are relatively simple. As such, it is safe and appropriate to be developed as an outdoor recreation-based tourism area taking into account each of the risk factors detailed above. Researchers also recommend limiting any outdoor recreation activities at Behrang Forest Reserve during the monsoon to avoid unwanted risks.

\section{Behrang Forest Reserve}

During field research, researchers found that the uniqueness of the flora and fauna at Behrang Forest Reserve was one of the major attractions. In this regard, the researcher proposes that further study could be done focusing on the inven- 
tory of flora and fauna found in the forest.

The Behrang Forest Reserve area is ideal for being one of the new outdoor tourism-based tourism destinations to develop the tourism sector in Muallim District. However, various aspects need to be developed and taken into account to make Behrang Forest Reserve one of the tourist attractions.

Infrastructure as well as complete information needs to be provided in advance to enable effective promotion Behrang Forest Reserve to the community or external tourists. The development of complete facilities and meeting the current tourism guidelines will help improve the quality and attractiveness of the area. The facilities to be provided should work well to meet the current demand and requirements of the tourism sector [7].

Each new development step should take into account the impact on local flora and fauna. Failure to care for biodiversity locally will have a negative impact in the long run. Therefore, the preservation of natural areas is important as well as attracting tourists to enjoy the beauty of the surroundings. The area to be developed should have convenient amenities such as roads to facilitate transportation such as buses or tourist vans to enter the area. Facilities such as lodging and toilets should be provided to facilitate local tourism. Other basic facilities such as pray room as well as parking areas should be provided by the relevant agencies. However, the development of all of these basic facilities should be minimal and will not have a negative impact on local flora and fauna and locals [9].

\section{Conclusions}

In conclusion, the researchers conclude that the Behrang Forest Reserve area is well-suited to serve as Malaysia's premier outdoor recreational tourism destination. In addition to having unique diversity of flora and fauna, the area is also surrounded by the Titiwangsa Range and surrounded by dozens of natural rivers. This attraction is one of the most popular outdoor recreation-based tourism products for tourists.

In addition to outdoor recreation-based tourism, eco-based tourism and edutourism are also among the products that could be introduced at Behrang Forest Reserve area. Researchers suggest advanced studies could also be carried out on a large scale so that the full potential of this area could be developed while helping to generate tourism economy in Muallim district and Perak state.

\section{Acknowledgements}

The authors would like to thank Sultan Idris Education University (UPSI) and Research Management and Innovation Centre (RMIC) of UPSI for providing Research Grant, University Research Grant project code: 2018-0205-108-01 and the facilities to carry out this research.

\section{Conflicts of Interest}

The authors declare no conflicts of interest regarding the publication of this paper. 


\section{References}

[1] Lee, B.H. and Chan, N.W. (2005) Pengurusan persekitaran 2005: Ekopelancongan dan orang asli di Cameron Highland. UKM, Bangi.

[2] Jamaludin, Md.J. (2009) Pembangunan pelancongan dan impaknya terhadap persekitaran fizikal pingir. Malaysian Journal of Environmental Management, 10, 71-88.

[3] Sidi, A., Aman, M.S. and Radzi, W. (2018) Persepsi Penggiat Rekreasi Terhadap Aktiviti Rekreasi Luar Yang Menjadi Keutamaan Di Gunung Ledang, Taman Negara Johor (Perception of Recreation Enthusiasts towards Main Outdoor Activity in Gunung Ledang, Taman Negara Johor). 1-9.

[4] Ahmad, M.Z. and Ibrahim, J.A. (2006) Pelancongan dan alam sekitar: Ekopelancongan sebagai alat untuk mencapai pembangunan pelancongan mapan dan meningkatkan kualiti persekitaran: Isu-isu dan pengurusan alam sekitar fizikal. Penerbit UPSI, Tanjong Malim, 95-116.

[5] Chung, A.Y., Paul, V. and Bosuang, S. (2020) The Insect Fauna of Tenompok Forest Reserve in Sabah, Malaysia. Journal of Threatened Taxa, 12, 15443-15459. https://doi.org/10.11609/jott.5588.12.4.15443-15459

[6] Eyisi, D. (2016) The Usefulness of Qualitative and Quantitative Approaches and Methods in Researching Problem Solving Ability in Science Education Curriculum. Journal of Education Practice, 7, 91-100.

[7] Schild, R. (2018) Fostering Environmental Citizenship: The Motivations and Outcomes of Civic Recreation. Journal of Environmental Planning and Management, 61, 924-949. https://doi.org/10.1080/09640568.2017.1350144

[8] Mohd, N.G. (2015) A Preliminary Flora Survey of Sungkai Wildlife Reserve Perak. Malaysian Journal of Wildlife and Parks, 29, 31-35.

[9] Choy, E.A. and Lazim, N.B.M. (2017) Tahap kefahaman ekopelancongan dalam kalangan komuniti local di Lata Jarum, Raub, Pahang. [Levels of Ecotourism Understanding among Members of the Local Community of Pahang's Lata Jarum, Malaysia.] Geografia-Malaysian Journal of Society and Space, 9, 27-34. 